\title{
Gaya Bahasa dalam Teks Iklan Produk Bermakna Asosiatif Pornografi
}

\section{(Language Style in Pornographic Associative Advertising Text)}

\author{
Sri Wiryanti Budi Utami \\ Program Studi Bahasa dan Sastra Indonesia, Universitas Airlangga \\ Jalan Dharmawangsa Dalam, Surabaya 60286 \\ Tel.: +62 (31) 5035676 \\ Surel: oetami_yanti@yahoo.co.id
}

Diterima: 31 Mei 2019 Direvisi: 7 Oktober 2019 Disetujui: 19 Desember 2019

\begin{abstract}
Abstrak
Penelitian ini bertujuan untuk mengungkap makna asosiatif pornografi yang terkandung dalam iklan yang disiarkan di Indonesia. Penelitian ini menggunakan metode kualitatif. Penelitian ini memakai sumber data majalah dan tabloid. Data iklan dikumpulkan berdasarkan kriteria produk bermuatan porno, meliputi data lingual dan data ekstralingual. Selanjutnya, data yang dianalisis difokuskan pada gaya bahasa yang terdapat dalam iklan. Hasil penelitian menunjukkan bahwa makna fitur dari iklan-iklan produk yang bersifat pornografi tersebut mengacu pada kode bahasa di sekitar organ intim dan hubungan intim yang direpresentasikan dalam bentuk figuratif, baik dalam elemen verbal maupun nonverbal. Bentuk figuratif mewakili fleksibilitas tanda bahasa yang tidak dianggap vulgar untuk mengurangi beban makna pornografi. Konten porno dikemas dalam gaya bahasa asosiatif dengan makna konotatif, stilistik, afektif, reflektif, dan kolokatif. Dengan demikian, semua kode figuratif yang terkandung dalam iklan-iklan produk yang bersifat pornografi yang dikaji dalam penelitian ini lebih memainkan peran penting dalam membangun citra khusus produk daripada menawarkan produk tersebut.
\end{abstract}

Kata kunci: asosiatif, figuratif, porno, simbolik

\begin{abstract}
This study aims to reveal the associative meaning of pornography contained in advertisements broadcasted in Indonesia. To achieve this goal, the researcher uses qualitative method. Data are taken from pornographic product advertisements in Indonesia. Furthermore, the data analyzed are focused on language style contained in the advertisements. The results show that the feature meaning of pornographic product advertisements refers to the language code around intimate organs and sexual intercourse that are represented in figurative form in both verbal and nonverbal elements. The figurative form represents the flexibility of language signs, not considered to be vulgar, in order to reduce the burden of pornographic meaning. Porn content is packaged in an associative language style with connotative, stylistic, avective, reflective, and collocative meanings. In other words, all those figurative codes contained in the pornographic product advertisements studied play an important role in constructing a special image of the products rather than in offering the products.
\end{abstract}

Keywords: associative, figurative, porn, symbolic

\section{PENDAHULUAN}

Iklan produk merupakan kegiatan nonpersonal dari sponsor menggunakan media untuk mempresentasikan dan mempromosikan sesuatu dengan membayar. Sebagai konsekuensinya, para pengiklan akan menampilkan teks seefektif dan seefisien mungkin untuk merebut perhatian publik. Teks berasosiasi makna pornografi dipandang tepat sebagai cara menarik perhatian dan mengatasi persaingan publik (Hall \& Bishop 2007:2; Bungin 2003:108). Isu-isu seputar representasi visual perempuan, hasrat seksual, dan praktik seksual menjadi unsur yang membagun teks pornografi (Attwood 2002: 91). 
Teks iklan produk cenderung menggabungkan aspek visual dan spesifikasi penempatan jenis huruf berkaitan dengan tata letak, desain, tipografi, kepentingan publikasi (Lee \& Johnson 2007:197). Sinergi aspek visual dan verbal dalam iklan produk guna mengelaborasi gagasan, di samping kelenturan (fleksibelitas) makna pesan (Munandar 1999:27). Hal senada dijelaskan Dyer (2008:104), iklan selalu melibatkan elemen-elemen visual seperti (1) ilustrasi dengan berbagai gaya dan atribut visual (2) simbol-simbol sebagai properti pendukung (3) setting (latar) dan warna, dan (4) produk yang diiklankan. Strategi menggabungkan bahasa verbal dan visual sebagai sarana utama dalam iklan (produk) menciptakan teks. Vihma \& Văkeva (2009:89) berpendapat bahwa menggabungkan aspek visual dan verbal, di samping menajamkan ekspresi linguistik untuk menghasilkan efek tertentu. Sebagai sarana penawaran, iklan produk merupakan kegiatan mengirimkan stimulus pesan pada konsumen yang dirancang dengan strategi tertentu untuk memengaruhi konsumen dan mendapat respons tindakan (membeli). Hagiyanto (2001:20) menjelaskan bahwa ukuran baik dan tidaknya, atau efektif dan efisiennya teks iklan produk sangat bergantung pada bahasa yang dapat berfungsi informatif dan persuasif, maka selain komunikatif, iklan harus bisa memancing respons konsumen. Keberhasilan iklan produk sebagai media penawaran bergantung pada seberapa teks dapat memengaruhi, membujuk, dan memberikan rasa kepercayaan dan loyal terhadap produk. Teks iklan produk harus mampu membangkitkan rasa ingin tahu, rasa ingin memiliki, rasa ingin menikmati, dan persuasi yang lain terkait dengan produk. Oleh karena itu, iklan produk merupakan desain komunikasi visual yang tidak hanya menyajikan fungsi produk, tetapi juga janji dan asosiasi-asosiasi yang bernilai persuasif.

Menurut Jefkins (1997:232), bahasa iklan memiliki ragam yang khas semacam ragam jurnalistik. Sifat ragam jurnalistik selain ringkas, juga padat dan sederhana. Aspek-aspek penandaan untuk mengungkapkan gaya, isi, fungsi dan asosiasi-asosiasi produk memerlukan gaya bahasa untuk menginformasikan dan mempersuasi agar mendapat respon yang memadai. Perlunya gaya bahasa tertentu dalam iklan karena teks dalam iklan produk harus mampu menampilkan tidak hanya logis, tetapi sederhana dan mudah dicerna. Dyer (2008:184) menjelaskan bahwa kesuksesan iklan bergantung pada tampilan teks yang tidak hanya logis, tetapi juga menimbulkan fantasi dan makna simbolis. Setiap pesan dalam iklan memiliki dua tingkatan makna, yakni makna yang dikemukakan secara eksplisit di permukaan dan makna implisit di balik permukaan tampilan makna (Noviani 2002: 79). Kecenderungan iklan produk menggunakan gaya bahasa tertentu untuk membentuk teks "well formedness," yakni penyampaian pesan dengan motivasi-motivasi tertentu dengan cara menarik perhatian. Dalam hal ini, teks tidak semata-mata bertumpu pada aspek gramatikal. Pemanfaatan gaya bahasa dalam iklan produk tecermin dari pilihan bentuk kata, frasa, atau kalimat untuk menghasilkan teks yang sarat dengan maksud. Hal ini berkaitan erat dengan prinsip iklan produk yang menekankan teks persuasif tanpa mendesak khalayak. Pemanfaatan gaya bahasa dalam teks iklan di antaranya untuk mengomunikasikan produk secara tersamar. Sebab, pada umumnya, teks iklan terkadang hanya sebagai pelengkap produk. Teks cenderung berupa kalimat tidak lengkap. Memahami gaya bahasa iklan harus dalam bingkai menganalisis secara sistematis fitur-fitur bahasa teks dan signifikansi fungsionalnya. Tujuannya, di samping mendiskripsikan fitur-fitur bahasa iklan, adalah untuk melihat implikasi dari efek yang dihasilkan.

Pada umumnya iklan dan khususnya iklan produk, pengungkapan bahasa verbal sengaja dibuat dengan gaya bahasa tertentu dengan penekanan keunggulan produk untuk menarik perhatian. Sebagai media persuasif, gaya bahasa asosiatif untuk mensugesti khalayak/konsumen. Keraf (2004:112) mengemukakan bahwa gaya atau gaya merupakan bentuk retorika menulis indah. Sebagai bentuk retorika, gaya digunakan untuk memberi efek tertentu. Gaya asosiatif memungkinkan terbentuk konotasi tertentu (Dale et al 1971:220). Pemanfaatan makna asosiatif, di samping untuk menunjukkan makna tambahan, dapat digunakan untuk mentautkan ingatan orang pada hal lain dan 
memunculkan pemahaman baru. Di samping itu, gaya asosiatif dapat untuk membandingkan suatu benda dengan hal lain.

Gaya dalam konteks retorika merupakan bahasa yang ikhas, indah, dan unik. Oleh karena itu, fungsi gaya bahasa termasuk dalam fungsi puitik. Jakobson (2011:359) menjelaskan fungsi puitik adalah fungsi bahasa untuk mempromosikan kelenturan tanda-tanda, menekankan dikotomi fundamental tanda dan benda. Dalam konteks ini dapat difahami, pemilihan gaya bahasa dalam iklan bermuatan porno bersifat unik, khas dan memiliki makna-makna asosiatif yang mengacu produk dan ilustrasinya. Keraf (2004 117-129) menjelaskan gaya bahasa mempertimbangkan (1) pilihan kata, (2) nada yang terkandung dalam wacana, (3) struktur kalimat, dan (4) langsung atau tidaknya makna. Dalam konteks ini, gaya bahasa melihat kesesuaian pilihan kata-kata yang memunculkan sugesti wacana, model kalimat, dan maknanya. Penggunaan bentuk figuratif merupakan salah satu gaya bahasa yang memanfaatkan makna tidak langsung yang berefek emotif dam evaluatif. Konstruksi dan kiasannya mencerminkan efek dan fungsinya.

Makna asosiatif pornografi dapat diungkapkan dalam bentuk figuratif. Bentuk ini menampilkan makna kias dan asosiatif. Kreidler (2013: 301) menjelaskan, "A figurative expression in which a notion is described in terms usually used for a defferent kind of notion." Bahasa iklan harus bisa memberi efek tertentu pada khalayak. Di samping itu, iklan juga harus mampu memengaruhi sikap, terutama pada iklan produk juga harus membangkitkan kesadaran khalayak terhadap produk yang ditawarkan. Iklan sering menggunakan gaya yang tidak terlalu "ketat" pada konvensi gramatika, bahkan dapat dikatakan iklan cenderung "mempermainkan" konvensi tersebut untuk memperoleh efek tertentu. Tidak jarang gaya bahasa yang digunakan menunjukkan penyimpangan dari bahasa "normal." Artinya, gaya bahasa iklan adalah bahasa yang berkarakteristik tidak dalam kodifikasi bahasa standar, tetapi dapat dalam bentuk yang merepresentasikan kelonggaran dan kebebasan yang dilandasi motivasi tertentu. Pemanfaatan gaya bahasa yang mengarah pada penyimpangan bahasa. Widdowson (1978:222) menjelaskan penyimpangan sebagai "by foregrounding is meant the delibrate deviation from rules of the language code for from the accepted convention of its use which stand out, or is foregrounding, againts a background of normal use." Penyimpangan bahasa merupakan penyimpangan terhadap kaidah-kaidah bahasa, yang bertentangan dengan penggunaan bahasa normal yang disengaja oleh pemakainya.

Makna asosiatif merupakan cara mengungkapkan makna secara samar-samar. Teks khususnya berkaitan dengan hal tabu memerlukan makna asosiatif (Tanaka 1999). Pengiklan cenderung menggunakan makna asosiatif untuk mensugesti suatu materi "porno" yang dipersepsikan tidak layak apabila ditampilkan secara eksplisit. Pada produk tertentu, makna asosiatif memiliki peran penting membentuk citra produk dan menghasilkan makna tambahan. Di samping itu, makna asosiatif memungkinkan sebuah iklan menjangkau makna lebih luas, di luar makna yang diungkapkan. Sebagai media persuasif yang bersifat publik, makna asosiatif cenderung diperlukan. Makna asosiatif dapat menghubungkan sesuatu yang berada di luar bahasa. Iklan bermakna asosiatif memiliki nilai komunikatif melebihi makna pesan dan respons terhubung dengan hal lain. Menurut Pateda (1996:160-162), makna asosiatif dapat mentautkan ingatan orang pada hal lain dan memunculkan pemahaman baru. Menurut Leech (2003:72), makna asosiatif dapat diklasifikasi berdasarkan makna konotatif, stilistik, makna afektif, makna reflektif, dan makna kolokatif. Makna konotatif digunakan untuk menimbulkan makna tambahan dari makna denotasinya. Makna stilistik untuk menimbulkan efek sosial yang merepresentasikan kekhasan konteks dan ekspresi penuturnya. Makna afektif untuk menimbulkan reaksi pada mitranya. Makna reflektif digunakan untuk menimbulkan daya sugestif atau daya emotif tertentu. Makna kolokatif adalah makna yang disampaikan dengan kata-kata yang 
cenderung berkolokasi dengan kata-kata tertentu untuk menimbulkan makna yang tepat sesuai konteksnya.

Pornografi secara umum dipahami sebagai sesuatu yang berkaitan dengan hasrat seksual, pasangan intim, alat vital, baik dalam ucapan atau tindakan (Hald \& Malumuth 2008). Gaya bermakna asosiatif pornografi digambarkan Tanaka (1999) pada iklan Haig Whisky, dengan slogan "Something that is more delicious than work." Ilustrasi perempuan dan botol produk, teks verbal ini memaknai 'Sex with me is more delicious than work' ('Berhubungan seks denganku lebih nikmat daripada bekerja'). Teks tersebut menunjukkan makna asosiatif pornografi mengarah pada makna gairah, kenikmatan seputar hubungan intim. Pornografi menurut KBBI (2013:1094) adalah (1) penggambaran tingkah laku secara erotis dengan lukisan, untuk membangkitkan nafsu birahi, mempunyai kecenderungan merendahkan kaum wanita; (2) bahan yang dirancang dengan sengaja dan semata-mata untuk membangkitkan nafsu seks.

Penggunaan gaya bahasa bermakna asosiatif pornografi pada iklan memuat pesan dan maksud tertentu. Di samping memperoleh respon dan berimplikasi pada fungsi dan tujuan sesuai produk tergambar pada Gambar 1.

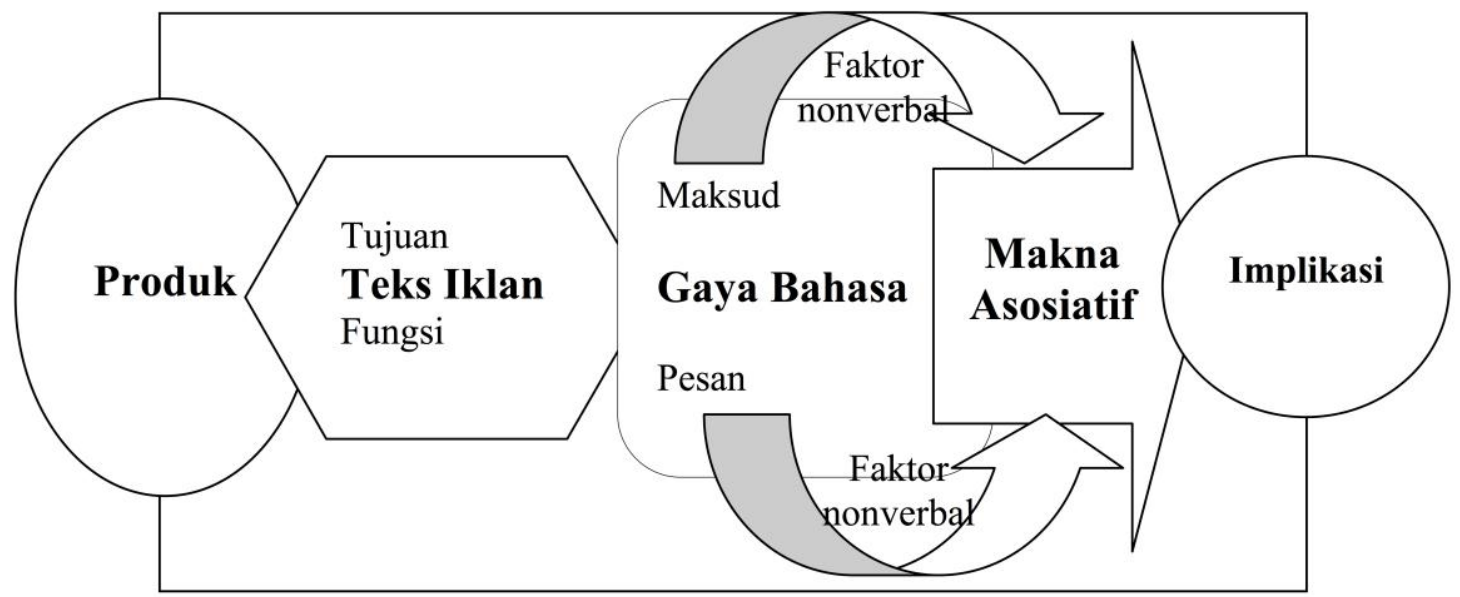

Gambar 1. Alur Gaya Bahasa Iklan Produk Bermakna Asosiatif

Gambar 1 menunjukkan bahwa teks iklan dibentuk dari mengaitkan produk, aspek verbal, dan nonverbal. Aspek nonverbal diperlukan karena banyak aspek iklan tidak dapat dideskripsikan secara keseluruhan dengan kata (Vihma \& Văkeva 2009:103). Short dan Hu (dalam Simpson 2001:604), menjelaskan proses interpretatif terhadap iklan tidak memungkinkan apabila tidak melibatkan material-material nonlinguistik, seperti; gambar, musik, dan gagasan-gagasan yang diilustrasikan.

Selaras dengan tujuan dan fungsinya, teks iklan menampilkan pesan dan maksud dengan gaya bahasa tertentu. Gaya gaya bahasa yang dipilih dapat menampilkan pesan dan mengisyaratkan maksud. Pemanfaatan fitur bahasa asosiatif, pengiklan mengharapkan teks yang ditampilkan berimplikasi mendorong khalayak pada ingatan dan tindakan. Makna asosiatif dalam gaya bahasa tidak langsung memungkinkan iklan dimaknai di luar makna pesannya. Di samping itu memungkinkan untuk memunculkan implikasi berkenaan dengan maksud dan tujuannya.

\section{METODE}

Iklan tidak dipandang sebagai entitas otonom yang maknanya dipahami tidak semata-mata dari aspek internal, tetapi diletakkan sebagai entitas dengan segenap karakteristik yang bersifat kontekstual. Ching et all (1980) menjelaskan, "to read a text as literature is not to make one's mind a tabula rasa and approach it without preconceptions." Membaca teks sebagai karya tidak boleh diperlakukan 
seperti menghadapi tabula rasa yang tidak berhubungan dengan konsepsi apa pun. Oleh karena itu, teks iklan sebagai produk dan tindakan harus dipahami berdasarkan karakter konteksnya.

Metode kualitatif merupakan hal yang tepat untuk memahami gaya bahaa iklan bermakna asosiatif pornografi. Penelitian ini memakai sumber data majalah dan tabloid. Data iklan dikumpulkan berdasarkan kriteria produk bermuatan porno. Penetuan muatan porno berdasarkan FGD dan kuesioner yang berisi tanggapan khalayak terhadap iklan yang memiliki tanda mengindikasikan hal porno. Analisis data menggunakan analisis makna tanda lingual dan ekstralingual. Analisis makna tanda lingual menggunakan teknik klasifikasi untuk memilah makna berdasarkan makna konotatif, stilistik, afektif, reflektif, dan kolokatif Analisis ekstralingual menggunakan teknik framing. Framing merupakan cara menemukan makna yang tersembunyi di balik sebuah teks, dari pesan yang diorganisir (Entman 1993:51). Oleh karena itu, analisis data menggunakan tahap-tahap (1) mendiskripsikan pilihan kata, kalimat, dan bentuk pengungkapan,(2) mendeskripsikan makna denotatif dan konotatif dari topik atau tema sentral iklan, dan (3) menginterpretasi makna teks dalam konteks.

\section{HASIL DAN PEMBAHASAN}

\section{Teks Iklan Produk Bermakna Asosiatif Pornografi}

Seperti iklan produk pada umumnya, iklan produk bermakna asosiatif pornografi memiliki struktur teks yang terdiri atas headline dan ilustrasi, bodycopy, dan tagline. Makna asosiatif pornografi cenderung berada pada headline didukung ilustrasi. Hal ini tidak lepas dari fungsi headline dan ilustrasi dalam iklan produk sebagai penarik perhatian khalayak. Dijelaskan oleh Russel (1999:447), "The headline is the most important part of an advertisment. It is first thing read, and should arouse interest to the consumer wants to keep on reading and get to know more about the product being sold." Teks bermakna asosiatif pornografi menekankan gaya bahasa tidak langsung. Ketidaklangsungan teks ini ditandai dari jarak antara pesan dengan kode yang ditampilkan. Artinya, pesan yang ditampilkan tidak dapat dimaknai terbatas pada pesan yang tersurat. Teks iklan memiliki makna tersirat dan berimplikasi pada sejumlah proposisi.

Gaya bahasa tidak langsung dalam iklan produk bermakna asosiatif pornografi cenderung menekankan makna tidak literal. Makna tidak literal bermakna asosiatif pornografi menempatkan teks bahasa simbolik dan figuratf. Kode bahasa bahasa ini digunakan untuk menyamarkan atau mengurangi kesan vulgar. Di samping itu, kode bahasa simbolik dan figuratif merupakan signifiying order. Artinya, merupakan kompleksitas tanda yang berkoherensi menurut cara tertentu dan dapat diramalkan ke dalam pola-pola representasi oleh individu atau kelompok untuk saling bertukar pesan.

\section{Gaya Bahasa Simbolik}

Teks iklan produk bermakna asosiatif pornografi cenderung dipaparkan secara simbolik. Baik aspek visual maupun verbal dikemas secara simbolik dan tidak literal, tetapi mampu memunculkan makna asosiatif pornografi seputar "alat vital," hasrat seksual yang berimplikasi pada tindakan hubungan intim disajikan dalam iklan kondom pada Gambar 2 dan Gambar 3. 


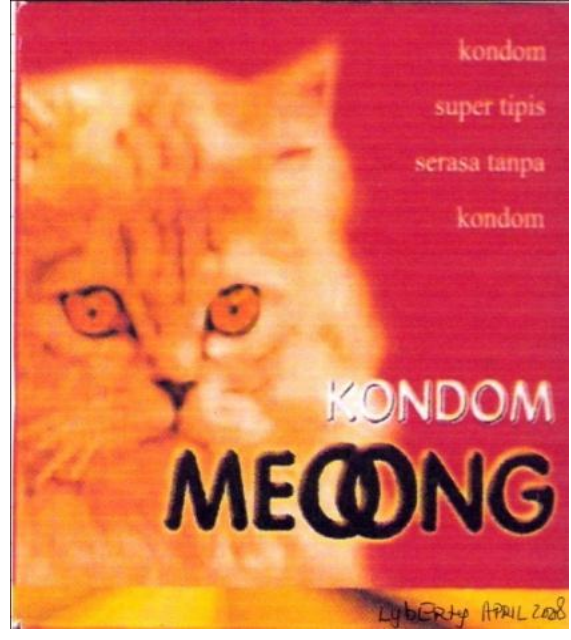

Gambar 2. Iklan Kondom Meong

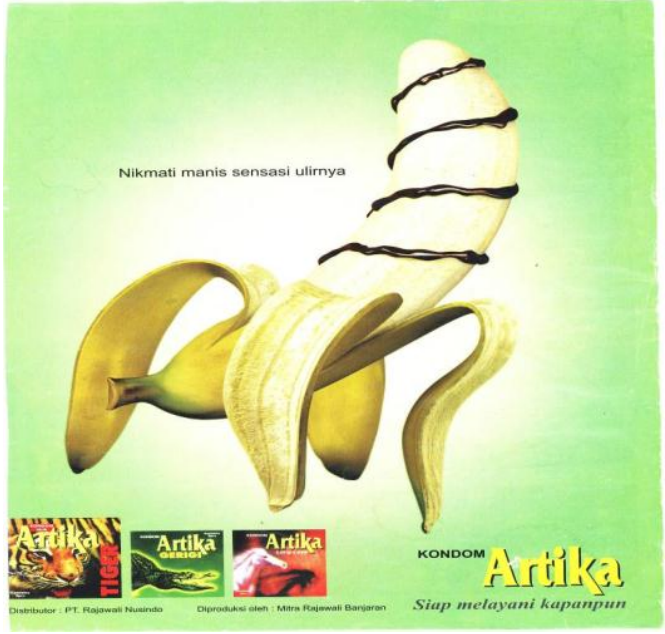

Gambar 3. Iklan Kondom Artika

Buah pisang pada Gambar 2, dalam pemahaman umum sering dikaitkan dengan organ intim lakilaki. Gambar pisang terlilit cokelat sebagai visualisasi (tanda nonlinguistik) mudah ditafsirkan dan mampu menyampaikan pesan tanpa disertai bahasa. Pengiklan memanfaatkan buah pisang dalam iklan kondom untuk menghubungkan kondom sebagai sarung pelindung organ intim. Teks "Nikmati manis sensasi ulirnya" dan gambar mendukung produk kondom secara mudah dapat ditafsirkan khalayak sebagai pesan informasi tentang produk kondom yang dapat memberi kenikmatan. Kata manis sebagai kata sifat yang lazim diacukan pada rasa makanan, minuman, atau ungkapan terhadap wajah, dalam iklan produk ini merupakan bentuk figuratif. Kata manis merupakan bentuk figuratif yang diacukan pada sentuhan kenikmatan berasosiasi pada makna kenikmatan merasakan sentuhan lembut organ intim saat berhubungan intim. Atribut kata sifat, seperti manis dan nikmat, merupakan cara pengiklan untuk menunjukkan kualitas produk yang menjajikan kenikmatan. Menurut Leech (1966:151), bahasa iklan cenderung menggunakan kata sifat untuk membantu pengiklan mendeskripsikan kualitas produk dan membangun sikap positif konsumen terhadap produk bersangkutan. Hal ini berkaitan dengan tujuan iklan, sebagai media persuasi. Kata sifat dalam iklan ini membentuk pesan dengan tujuan tersirat membangun sikap positif terhadap produk kondom yang ditawarkan. Teks "Nikmati manis sensasi ulirnya" seolah-olah penutur berbicara langsung dan mitra tuturnya memahami apa yang dimaksudkan. Dalam percakapan tatap muka, model teks tersebut dapat dipahami. Teks iklan dalam bahasa verbal merupakan realisasi bahasa lisan pada peristiwa interaksi komunikasi tatap muka. Model percakapan lisan rupanya menjadi salah satu cara pengiklan menyamarkan muatan porno yang disisipkan. Dengan menekankan makna afektif, muatan porno digunakan untuk melengkapi produk daripada menawarkan produk. Melalui bahasa verbal langsung tidak luteral, muatan porno bermakna afektif untuk mengasosiasi khalayak merasakan kenikmatan seksual.

Sementara itu, kucing pada Gambar 3 merupakan hewan yang dikaitkan dengan peliharaan yang dimanjakan. Pemanfaatan gambar kucing dalam iklan kondom untuk menghubungkan manfaat kondom yang memanjakan. Teks "Kondom Meong, Kondom super tipis, serasa tanpa kondom" memanfaatkan gaya bahasa figuratif. Melalui teks asertif mengasosiatif khalayak bahwa "kondom meong memberi sentuhan lembut.” Teks diharapkan berimplikasi memengaruhi konsumen untuk membeli produk yang memberi kenikmatan intim. Paralanguage meong dengan wajah manis kucing berbulu lembut memaknai suara manja mengharapkan belaian sayang. Menurut Cook (2001:64), paralanguage adalah perilaku bermakna yang menyertai bahasa. Dalam tuturan, perilaku bahasa tercermin dari kualitas suara, tempo, gerakan, ekspresi wajah dan sentuhan. Berkaitan dengan produk 
kondom, kata meong berkonotasi pada belaian, sentuhan, manja. Konotasi menyangkut asosiasi budaya yang umumnya dipahami oleh masyarakat sebagai bentuk tambahan makna dari kata (Jackson 2007:57). Kata meong dan ilustrasi di atas pada produk kondom memunculkan makna asosiatif pornografi "sentuhan yang memanjakan."

\section{Gaya Bahasa Figuratif}

Bentuk figuratif cenderung dimanfaatkan pada teks iklan produk bermakna asosiatif pornografi. Bentuk figuratif memungkinkan makna pada tataran pesan dan maksud. Bentuk figuratif dalam iklan seringkali mengadopsi ungkapan-ungkapan yang berkembang di masyarakat. Misalnya, "Ini kacangku" dalam iklan produk kacang Garuda dengan ilustrasi laki-laki menatap bagian buah dada wanita. Secara figuratif, kacangku berasosiasi pada puting susu, karena kacang dan puting susu memiliki kemiripan bentuk. Iklan produk berasosiatif porno sering memanfaatkan tanda dan simbolsimbol untuk menyamarkan yang sensitif. Penggambaran atau penuturan pornografis untuk pembangkitan hasrat seksual, tidak terlalu bersifat terang-terangan (Wijana 2003:209).

Dalam konteks budaya setempat (Indonesia), masyarakat mengenal kata-kata, istilah, atau ungkapan yang berasosiasi pada makna pornografi, seperti apem, bikang, tempe, dan bibir bawah yang digunakan untuk menyebut vagina. Untuk menyebut organ intim laki-laki digunakan istilah burung, rudal, tongkat, pisang ambon. Demikian pula untuk menyebut perilaku yang berkenaan dengan aktivitas hubungan intim, sering kali digunakan istilah kuda liar, raja di ranjang, selimut hidup, dan makin hot. Untuk menghindari kesan vulgar, ungkapan bermakna porno dinyatakan secara tersamar. Ungkapan dengan bentuk figuratif menjadi lebih halus. Di sampng itu, untuk keperluan eufimisme dan menghindari kesan seronok yang ditabukan dalam berbahasa.

\section{Makna-makna dalam Gaya Bahasa Asosiatif}

Proses mengomunikasikan makna asosiatif pornografi dalam iklan produk media cetak berkaitan erat dengan memahami ungkapan yang ditabukan dan gaya yang digunakan. Berkaitan dengan konteksnya, iklan produk bermakna asosiatif porno menggunakan gaya bahasa asosiatif dengan menekankan makna-makna berikut.

\section{Gaya Bahasa Asosiatif Bermakna Konotatif}

Gaya asosiatif dengan makna konotatif digunakan untuk mengomunikasikan sesuatu di luar makna acuannya. Menurut Kreidler (2013:38), "Connotation refers to personal aspect of meaning, the emotional asscociations that the words arouses. Connotations vary according to the experiences of individuals but, because people do have common experiences, some words have shared connotations." Konotasi dapat memberikan asosiasi pada makna yang berkembang di masyarakat sebagai pengetahuan bersama, selain berkait dengan pengalaman individu. Misalnya, ungkapan "Pemanasan Sebelum Main" berkonotasi pemanasan sebelum melakukan hubungan intim. Makna konotatif dapat dilihat dalam teks verbal "Kalau stamina prima mainnya bisa tahan lama" pada iklan produk suplemen dengan ilustrasi perempuan membawa produk bila ditempelkan pada buah dadanya. Kata mainnya pada konteks produk ini dapat berkonotasi pada aktivitas hubungan intim. Konotasi yang mengacu pada hubungan intim ini juga dapat dilihat pada teks "Jangankan 5 tahun sekali, nyoblos 3 kali sehari aja sanggup." Kata nyoblos berkonotasi alat intim ketika melakukan hubungan intim. Dua teks ini menggunakan kalimat langsung tidak literal, yang bersifat deskriptif. Muatan porno tidak digunakan untuk menawarkan produk secara langsung, tetapi untuk melengkapi kualitas atau kehebatan produk. 


\section{Gaya Asosiatif Bermakna Stilistik}

Makna stilistika merupakan makna yang merepresentasikan kekhasan penggunaan bahasa sesuai konteks dan ekspresi penjiwaan penuturnya. Misal, sapaan abang atau sayang merepresentasikan makna kedekatan. Dalam konteks produk bermakna asosiatif pornografi, makna stilistik dapat dilihat pada teks "Semprotkan saja sayang...." Kata sayang menandai kedekatan di antara partisipan. Pada konteks produk kondom dapat mengacu pada pasangan intim. Penggunaan kata semprotkan memperkuat makna kata sayang sebagai pasangan intim. Makna stilistika juga dapat dicermati pada iklan produk suplemen. Dalam teks "Suamiku lebih mantab" pada konteks produk suplemen, kata suamiku lebih diartikan sebagai pasangan intim. Kata mantab merupakan bentuk figuratif sebagai kata yang bermakna dapat memberi kepuasan. Kendati dinyatakan secara elipsis, muatan porno dapat dimaknai mantab memberi kepuasan dalam hubungan intim.

\section{Gaya Asosiatif Bermakna Afektif}

Makna afektif mencerminkan ungkapan ekspresif seseorang yang dapat memancing reaksi. Pada teks iklan bermakna asosiatif pornografi dapat dilihat pada teks "Siap dijajal" dengan ilustrasi wanita bergaya sensual. Penggunaan kata dijajal sebagai kata serapan alih-alih kata dicoba merupakan cara pengiklan menawarkan produk layanan yang perlu direspons. Penekanan kata siap dengan ilustrasi perempuan sensual memberi ketegasan bahwa layanan dijamin memuaskan. Bentuk figuratif dijajal dalam konteks "layanan kencan" dapat memunculkan respons khalayak untuk mencoba pelayanan yang memberi kebebasan. Muatan porno secara samar-samar dapat dimaknai layanan kencan yang siap dengan layanan seksual.

\section{Gaya Asosiatif Bermakna Reflektif}

Makna reflektif adalah yang makna disampaikan melalui asosiasi dengan pengertian yang lain dari ungkapan yang sama. Makna ini digunakan untuk menimbukan daya sugestif atau daya emotif tertentu. Menurut Leech (2003:33, makna reflektif digunakan untuk mengungkapkan sesuatu yang berbeda dari makna konseptualnya, dan direspons dengan makna lain. Misalnya teks "Inilah pilihan tunggangan Anda" dengan ilustrasi wanita dalam posisi siap menerima beban penunggangnya. Kata tunggangan secara sugestif dapat diacukan pada sejenis kendaraan yang siap mengantar orang ke tempat yang diinginkan. Dalam konteks produk ban kendaraan dan didukung ilustrasi, dapat digunakan menunjukkan produk ban berkualitas yang memberi kenyamanan pada kendaraan. Teks dan konteks dapat menimbulkan daya emotif dan sugestif seputar muatan porno tentang kenyamanan naik kendaraan seperti menikmati perempuan dalam hubungan intim.

\section{Gaya Asosiatif Bermakna Kolokatif}

Makna kolokatif adalah makna yang disampaikan dengan kata-kata yang cenderung berkolokasi dengan kata-kata tertentu untuk menimbulkan makna yang bernuansa lebih. Misal, teks "Stamina prima mainnya bisa tahan lama." Kolokasi antara kata stamina dan prima memunculkan makna tidak sekadar daya tahan, tetapi mengacu pada tubuh bugar dan memiliki daya tahan kuat. Kolokasi antara mainnya dan tahan lama memunculkan makna tidak sekadar bisa bermain, tetapi aktivitas bermain yang menyenangkan karena bisa berlangsung lama. Dalam konteks produk suplemen dan ilustrasi pasangan mesra, muatan porno pada makna kolokasi tersebut dapat mengacu pada seputar hubungan intim.

Bentuk figuratif dari kata-kata yang dipilih, seperti nyoblos, on, hot, dan semprotkan, masih dalam kerangka makna yang diacukan pada makna dasarnya. Misal, kata semprotkan dapat dimaknai mengeluarkan air dari saluran dengan semburan yang deras; secara kognitif dalam produk bermuatan porno dapat dihubungkan pada aktivitas hubungan intim saat pasangan mencapai puncak. Dalam produk kondom, kata semprotkan dapat digunakan untuk menndeskripikan fungsi dan manfaat 
menggunakan kondom. Bentuk figuratif dalam iklan produk untuk melengkapi penawaran produk daripada menawarkan secara langsung. Dengan kata-kata yang tidak berkesan vulgar, melalui paparan deskriptif, pesan teks dapat termaknai sesuai dengan tujuan penawaran, di samping mengurangi beban makna porno yang dimunculkan. Demikian halnya pada produk suplemen atau vitamin vitalitas tubuh, muatan porno diacukan pada makna seputar organ intim dan hubungan intim. Bentuk figuratif pada kata on sebagai kata serapan yang bermakna 'hidup,' pada teks "Minum 1 kapsul langsung on" dalam produk dan ilustrasi pasangan intim, kata on dapat dihubungkan pada makna 'ereksi'. Demikian pula kata mantap pada "Suamiku lebih mantap," kata action pada "2 x sehari siap action," kata nyoblos pada "Nyoblos 3 x sehari sanggup," merupakan kata figuratif mengungkapkan makna akivitas seputar hubungan intim.

Masyarakat pada umumnya memahami kata hot, tunggangan, pelet, dan pria sejati berkonotasi pada hal porno. Kata hot bermakna panas dapat berasosiasi pada makna gairah atau seputar adegan hubungan intim. Sementara kata tunggangan dalam bahasa Jawa bermakna kendaraan sering dikaitkan dengan sesuatu yang berhubungan dengan kenikmatan maka dalam iklan mobil cenderung menggunakan perempuan bergaya sensual sebagai ilustrasinya. Kata pelet sering dihubungkan dengan sesuatu yang dapat digunakain untuk menarik perhatian. Kata pelet dalam budaya Jawa mengacu pengasihan, yakni sesuatu yang memiliki kekuatan agar sesorang jatuh cinta. Oleh karena itu, orang yang berprofesi sebagai "penjaja cinta" dipandang menggunakan pelet sebagai alat agar orang mudah terperangkap pada bujuk rayu. Kata pria sejati atau pria tulen memaknai laki-laki yang mampu berhubungan intim dengan lawan jenisnya. Sebutan "pria sejati" ini sering dilawankan dengan sebutan "banci" sebagai penamaan laki-laki yang tidak bisa berhubungan intim dengan lawan jenisnya atau sebutan untuk laki-laki yang berkarakter seperti perempuan. Sebutan "pria sejati" juga sering digunakan untuk menandai laki-laki yang kuat dan mampu memberi kepuasan dalam berhubungan intim.

Iklan dapat menggunakan teks yang mengandung makna di luar makna pesannya. Sebagai karya desain, maka membaca teks iklan tidak ubahnya membaca karya sastra, maka perlu pemahaman di luar paparan pesannya. Eagleton (1983:60) menjelaskan "meaning is not simply something expressed or reflected in language: it is actually produced by it" ('memaknai tidak hanya sebagai sesuatu yang diekspresikan atau direfleksikan bahasa, memaknai merupakan aktualisasi yang sebenarnya dihasilkan'). Iklan produk cenderung menggunakan bahasa deskriptif dengan metafora, personifikasi, dan kata sifat dengan konotasi yang menguntungkan dalam penawaran produk. Dalam konteks ini, iklan produk bermuatan porno sering menggunakan pilihan kata yang sudah menjadi perbedaharaan umum dapat mewakilinya. Kata hot, meong, besar, gede, nikmat, gairah, anunya, nyoblos, dan loyo dapat dihubungkan hal porno seputar alat intim dan hubungan intim. Sejumlah kata ganti seperti -nya dalam mainnya dan gedenya untuk membangun hubungan yang lebih dekat dengan khalayak target yang dituju.

Sebagai bentuk komunikasi persuasif, iklan memiliki fitur khusus seperti menggabungkan elemen verbal dan nonverbal. Muatan "porno" semakin dapat dipahami apabila dihubungkan dengan ilustrasi. Dalam iklan produk, gambar dan gerakan sering ditampilkan lebih ekspresif daripada bahasa itu sendiri, seperti gambar kucing dengan bulu lembut lebih eskpresif daripada dinyatakan dengan lembut dan manja. Gambar tersebut akan terhubung pada sosok yang manja dan membuat orang ingin membelai bulu-bulunya yang lembut. Maka, produk kondom dengan menampilkan kucing tersebut akan mudah dipahami bahwa kondom yang ditawarkan merupakan kondom yang lembut dan sentuhannya memanjakan pasangannya. Tanpa diungkapkan panjang lebar, teks kondom "Tipis serasa tanpa kondom" dengan ilustrasi wajah kucing bebulu lembut dapat memberi informasi pada khalayak potensialnya bahwa produk tersebut adalah kondom yang lembut dan menghubungkan pada seputar hubungan intim. Seperti halnya gambar pisang berulir cokelat. Buah pisang bersaput 
uliran cokelat lebih ekspresif bila dinyatakan dengan "lezat dan nikmat." Buah pisang sering dihubungkan pada alat kelamin pria. Dalam konteks produk kondom, teks "Nikmati sensasi ulirnya" diarahkan pada tujuan produk. Secara asosiatif menghubungkan khalayak pada kenikmatan berhubungan intimnya.

Sebagai komunikasi publik dengan keterbatasam ruang dan waktu, iklan menggabungkan elemen verbal dan nonverbal memungkinkan untuk menyampaikan semua pesan dan maksud sesuai tujuan Pengiklan harus menarik khalayak potensial sebanyak mungkin, tanpa menimbulkan kesan 'vulgar' dan memaksa. Berkaitan dengan tujuan persuasif dengan mengharap respon tindakan khalayak, pengiklan menekankan pada relasi kedekatan, kesekawanan, dan kesetaraan. Gaya percakapan dengan paparan deskriptif merupakan gaya yang paling banyak ditampilkan, sepeti tecermin pada kelima teks berikut: (1) " 2 x sehari siap action penuh stamina penuh gairah," (2) "Jangankan 5 tahun sekali, nyoblos 3 kali sehari aja sanggup," (3) "Dengan mencap suamiku lebih mantap!" (4) "Kalau stamina prima mainnya bisa tahan lama," dan (5) "Stamina lelaki siang dan malam."

Gaya percakapan dengan paparan deskriptif ini tidak semata-mata untuk menawarkan produk, tetapi untuk melengkapi produk. Melalui muatan porno, khalayak potensial diajak membayangkan kehebatan produk. Teks verbal dengan paparan deskriptif merupakan cara paling "lunak" dalam memberi kelonggaran (Huang 2017:106; Kreidler 2013:183). Di samping bersifat informatif menunjukkan kelebihan produk, paparan deskriptif bersifat persuasif sebagai cara mendesak dengan cara halus karena tidak bersifat direktif. Paparan tidak menggunakan verba langsung yang bersifat "konfliktif" tertuju pada memaksa mitranya. Muatan porno diungkapkan secara tidak literal dan digunakan melengkapi kehebatan produk. Pilihan kata bermuatan porno secara kognitif sudah menjadi skema pengetahuan bersama. Oleh karena itu, muatan porno cenderung menggunakan kata figuratif, sebagai cara menyamarkan makna selain mengurangi kesan vulgar.

Kecenderungan pengungkapkan makna secara tidak literal merupakan salah satu karakteristik iklan sebagai komunikasi bertujuan yang bersifat samar-samar. Menggunakan makna asosiatif sebagai salah satu strategi iklan bertopik seperti seks, gender, atau tabu. Dengan makna asosiatif dimungkinkan para pengiklan menghindari pertanggungjawaban atas dampak-dampak sosialnya. Muatan porno secara literal dipandang vulgar dan dapat menimbulkan cemooh atau memuakkan karena dianggap tidak senonoh, bahkan iklan akan segera ditarik dari peredaran. Keberhasilan iklan menawarkan produk adalah mendorong konsumen untuk membeli, dengan menghindari ungkapan vulgar, tetapi merayu khalayak konsumen dengan mengurangi beban psikologis mereka pada saat berbelanja. Penggunaan makna asosiatif memungkinkan para pengiklan memikat calon konsumennya dengan metafora verbal dan non-verbal.

Iklan bermakna asosiatif pornografi cenderug menghindari kesan vulgar. Oleh karena itu, pengiklan menggunakan gaya tertentu sebagai strategi pengungkapannya. Dalam konteks ini, pengiklan menggunakan skema pengetahuan yang sama dengan khalayak terhadap isu porno dan acuan porno yang bersifat samar-samar. Sperber \& Wilson (1995:15-16) menjelaskan, "A speaker who intends an utterance to be interpreted in a particular way must also expect the hearer to be able to suply a context which allows that interpretation to be recovered. A mismatch between the context envisaged by the speaker and the one actually used by the hearer may result in misunderstanding." Pengiklan dapat membuat iklan bermuatan "porno" tanpa menyebabkan khalayak merasa risih, tetapi menjadi ingatan yang diharapkan khalayak konsumen sesuai dengan konteks yang melingkupi. Senada dijelaskan oleh Leech (1983:13), "background knowledge assumed to be shared by S (speaker) and H (hearer) and which contributes to H's interpretation of what $S$ means by given utterance." Menampilkan muatan porno perlu dilandasi latar belakang pengetahuan yang sama dengan khalayak konsumen, sehingga makna asosiatif yang dimunculkan pada sesuatu yang diacu dapat termaknai 
tanpa pengungkapan yang vulgar. Hal ini memperlihatkan latar belakang pengetahuan sesungguhnya merupakan konteks yang mampu menjabarkan makna di balik pesan yang dimunculkan. Informasi kontekstual adalah informasi yang dapat digunakan sebagai latar belakang pengetahuan yang samasama dipahami oleh penutur (pengiklan dan khalayak) untuk memaknai teks. Sesuatu yang dipahami bersama di antara penutur dapat terjadi karena memiliki kesadaran kolektif yang sama. Hal ini yang perlu dipahami pengiklan untuk memanfaatkan seluruh potensi elemen verbal dan nobverbal merepresentasi gagasan dan memperoleh efek tertentu (Saeed 2003:300; Jefkins 1977: 232).

Pengetahuan tentang produk juga dapat menjadi dasar teks mengemas muatan porno. Misal, pengetahuan tentang produk kondom dapat menghubungkan proposisi- proposisi seputar kondom (1) sebagai sarung pelindung dari resiko kehamilan ketika berhubungan intim, (2) terbuat dari bahan elastis yang tipis dan lembut, (3) tidak mengurangi rasa nikmat, (4) memberi kebebasan pasangan intim mencapai kepuasan. Kendati teks iklan bersifat ringkas dan simbolik, khalayak konsumen dapat dengan mudah menghubungkan pada fantasi seksual seputar hubungan intim. Barthes (1977) menjelaskan bentuk simbolik merupakan cara penandaan dengan menggunakan objek sebagai simbol ketika diakui melalui konvensi dan maknanya memungkinkan mewakili hal lain (Fiske 2012:150).

Makna asosiatif dengan paparan bahasa deskriptif pada iklan untuk mengurangi beban produk bermuatan porno. Ketersamaran teks bermuatan porno merupakan cara iklan menghubungkan teks dengan semua manfaat/keuntungan yang akan dimiliki khalayak konsumen. Komunikasi samarsamar untuk menghindarkan resiko atas konsekuensi dari dampak negatif dari muatan porno yang dimunculkan. Penyamaran pesan teks bermuatan porno tidak secara eksplisit meyakinkan produk, tetapi dalam kesatuan makna yang dapat menghubungkan pada keuntungan (vitalitas tubuh dan keintiman) yang akan dimiliki khalayak konsumen. Pada iklan, khususnya iklan produk, teks tersamar digunakan untuk mengomunikasikan produk dengan informasi yang berkesan melengkapi produk daripada menawarkan produk. Iklan sesungguhnya merupakan teks yang mnggabungkan antara pengetahuan dan penafsiran dari informasi yang dikomunikasikan secara tersamar. Muatan porno dapat efektif menarik perhatian karena khalayak sudah memiliki pengetahuan yang memungkinkan untuk menafsirnya. Sebagaimana dinyatakan Tanaka, "the cognitive system of human beings is organised in such a way that it is more susceptible to this kind of information [i.e. sexual] than to other kinds" ('sistem gagasan manusia diatur sedemikian rupa agar mudah terpapar jenis informasi berkaitan dengan seks'). Latar belakang pengetahuan (pengiklan-khalayak konsumen) dapat membantu pemahaman terhadap teks.

\section{SIMPULAN}

Sebagai bentuk komunikasi, iklan memiliki fitur khusus. Iklan adalah kombinasi komunikasi yang menggabungkan elemen verbal dan non-verbal. Dalam konteks iklan produk, elemen nonverbal lebih ekspresif daripada elemen verbalnya, namun bahasa verbal tetap menjadi media komunikasi yang cukup signifikan dalam mengirimkan informasi. Hal ini ditunjukkan sebagaian besar iklan menggunakan elemen verbal dan nonverbal. Paparan deskriptif dengan menyinergikan aspek verbal dan nonverbal digunakan untuk mengungkapkan proposisi pada fungsi dan tujuan iklan. Sebagai media publik dan sebagai komunkasi searah nontatap muka, iklan harus menarik perhatian dan informasi tersampaikan Dalam konteks ini, iklan cenderung menggunakan gaya bermakna asosiatif untuk menarik perhatian. Iklan bermakna asosiatif pornografi cenderung menggunakan bentuk figuratif untuk menghindari kesan vulgar. Makna asosiatif baik dalam makna konotatif, afektif, stilistik, reflektif, kolokatif digunakan untuk melengkapi produk daripada menawarkan produk. Pengungkapan dengan makna-makna ini, pengiklan dapat mendeskripsikan makna tanpa "beban." Di samping itu, secara "utuh" makna tersampaikan dengan implikasi yang diharapkan. 


\section{DAFTAR PUSTAKA}

Attwood, F. 2002. "Reading Porn: The Paradigm Shift in Pornography Research." Sexualities 5 (1):91105.

Bungin, Burhan. 2003. Pornomedia: Konstruksi Sosial Teknologi Telematika EF Perayaan Seks di Media Massa. Jakarta: Pranada Media.

Ching, M.K., M.C. Haley \& R.F. Lunsford. 1980. "The Theoretical Relation between Linguistic and Literary Studies: An Introduction by Editors." Dalam Linguistic Perspectives on Literature. London: Routledge \& Kegan Paul.

Cook, G. 2001. The Discourse of Advertising. London: Routledge.

Crook, J. 2004. "On Covert Communication in Advertising." Journal of Pragmatics 36 (4):715-738.

Dale, E. et al. 1971. Techniques of Teaching Vocabulary. Palo Alto, California: Field Education Publication, Inc.

Dyer, G. 2008. Advertising as Communication. New York: Routledge.

Entman, R.M. 1993. "Framing: Toward Clarification of a Fractured Paradigm." Journal of Communication 43 (4):51-58.

Fiske, J. 2012. Pengantar Ilmu Komunikasi. Jakarta: Rajawali Pers.

Hagijanto, A.D. 2001. "Simbol Budaya sebagai Representasi Positioning dalam Iklan Produk Mobil Eropa dan Mobil Jepang." Nirmana 8 (2):20-23.

Huang, Y. (Ed.). 2017. The Oxford Handbook of Pragmatics. Oxford: Oxford University Press.

Hall, A. C \& M.J. Bishop. 2007. "Pornography-Sex in Mass Media.” Pop-Porn: Pornography in American Culture I. London: Praeger Publishers.

Jackson, H. \& E. Ze Amvela 2007. Words, Meaning and Vocabulary. London: Continuum International Publishing Group Ltd.

Jefkins, F. 1997. Periklanan. Jakarta: Erlangga.

Keraf, G. 2004. Diksi dan Gaya Bahasa. Jakarta: PT Gramedia Pustaka Utama.

Kreidler, C.W. 2013. Introducing English Semantics. London \& New York: Routledge.

Leech, G. 1983. Principles of Pragmatics. New York: Longman.

Lee, M. \& C. 2007. Prinsip-prinsip Pokok Periklanan dalam Perpektif Global. Jakarta: Kencana Prenada Media Group.

Noviani, R. 2002. Jalan Tengah Memahami Iklan.Yogyakarta: Pustaka Pelajar. 
Munandar, U. 1999. Kreativitas dan Keberbakatan Strategi Mewujudkan Potensi Kreatif dan Bakat. Jakarta: Gramedia Pustaka Utama.

Saeed, J.I. 2003. Semantics. Malden: Blackwell Publisher Inc.

Sperber, D. \& Wilson. D. 1995. Relevance: Communication and Cognition. Oxford: Blackwell.

Tanaka, K. 1994. Advertising Language: a Pragmatic Approach to Advertisements in Britain and Japan. London: Routledge.

Vihma, S. \& S. Văkeva. 2009. Semiotika Visual dan Semantika Produk, Pengantar Teori dan Praktik Penerapan Semiotika dalam Desain. Yogyakarta \& Bandung: Jalasutra.

Widdowson, H.G. 1978. Teaching Language as Communication. Oxford: Oxford University Press.

Wijana, I. 2003. Kartun: Studi tentang Permainan Bahasa. Yogyakarta: Ombak. 